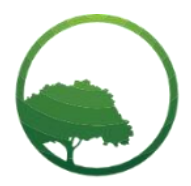

Research in Business \& Social Science

IJRBS VOL 10 NO 7 ISSN: 2147-4478

\title{
Investigating the moderating effect of the demographic factors on post-purchase regrets at malls in Sri Lanka
}

\author{
(iD) E.A.S.K. Ekanayake ${ }^{(a) *(10) \text { E.A.C.P. Karunarathne }}{ }^{(b)}$ \\ ${ }^{(a, b, c)}$ Department of Industrial Management, Wayamba University of Sri Lanka, Kuliyapitiya 60200, Sri Lanka
}

\author{
A R T ICLE INFO \\ Article history: \\ Received 07 October 2021 \\ Received in rev. form 30 Oct. 2021 \\ Accepted 05 November 2021 \\ Keywords: \\ Post-purchase regret, Alternatives, \\ Return process, Buying experience, \\ Shopping Malls, Moderating Effect \\ JEL Classification: \\ L80, L81, M30, M31
}

\begin{abstract}
A B S T R A C T
As of 2020, the retail sector faced an existential challenge with rapid changes as one of the many sectors. The recent impact was noted due to the present COVID-19 pandemic throughout the world. Most customers have moved on with e-commerce platforms, while traditional customers still struggle with in-store shopping. This study was specifically aimed at the conventional customers who do instore shopping in complexes. The objective of this study was to investigate the moderating effect of the demographic factors on post-purchase regret at malls. Two factors affecting post-purchase regret, namely, number of alternatives forgone and return process experience, were considered. Accordingly, the moderating effects of demographic factors of consumers who have purchased something from a shopping mall during the past two years were targeted for this. By conducting an online survey using a structured questionnaire, 383 responses were collected. Through the moderation effect analysis, the consumer career was identified as moderating variable for this relationship. The rest of the demographic factors considered for this study did not significantly moderate this relationship. The findings suggest that the number of alternatives in showcase must be limited with a sense of marketing. Further, the staff at the shop must provide proper guidance on the return process and related service by identifying loyal and non-loyal customers' careers and lifestyles.
\end{abstract}

(C) 2021 by the authors. Licensee SSBFNET, Istanbul, Turkey. This article is an open access article distributed under the terms and conditions of the Creative Commons Attribution (CC BY) license (http://creativecommons.org/licenses/by/4.0/).

\section{Introduction}

The satisfaction level of a consumer is a measurement that cannot quantify easily. The experience of a product or service can lead to a delighted moment or a total dissatisfaction. The evaluation of such an experience can be done as a pre-purchase evaluation or as a post-purchase evaluation. In post-purchase evaluation, regret can be identified as a consequence of dissatisfaction (Moakhar et al., 2018a). There can be numerous reasons for a post-purchase regret. Usually, wrong judgments are mainly caused to regrets (Clarke \& Mortimer, 2013). In this study, implications of the number of alternative forgone and return process experiences were only considered.

An alternative is a possible option that has to a person. With that, alternative forgone can be defined as the given-up option over the selected option (Myers, 2004). For example, at a shopping mall, a person may have two favourite options, but he/she has to choose one out of them. If the option he/she decided was found to be unfit to his/her perceived level, the regret for the alternative forgone appears in such incidents. According to the study of Moakhar et al. (2018a), the number of alternatives has a significant impact on post-purchase regret. The same concept had been noted by Rai and Kimmel (2015), and a positive relationship was recognized between the two variables.

In the retailing sector, shops have implemented many strict returning policies to control product returns. The primary purpose of these return policies is to avoid customer regrets that occur from buying decisions. Even though these returning policies have less impact on product return (Tan \& Gan, 2014). One such returning policy in retail stores is adding a restocking fee for each return provided (Zou, Zhou, \& Jiang, 2020). Usually, they set a higher restocking fee for high-quality products while setting a lower fee for

* Corresponding author. ORCID ID: 0000-0003-2673-4371

(C) 2021 by the authors. Hosting by SSBFNET. Peer review under responsibility of Center for Strategic Studies in Business and Finance. https://doi.org/10.20525/ijrbs.v10i7.1463 
low-quality products. Further, to avoid returns, retail stores set restocking fees for the same priced alternative in the shop. A mathematical representation was pronounced by Zou, Zhou, and Jiang (2020) for this restocking fee. It was noted that restocking fees extract all the surpluses that consumers can gain from product returns. Also, the returning price and the restocking fee tally with this phenomenon. Mollenkopf et al. (2007) stated that effort leniency increases return procedure satisfaction with the customer while decreasing anticipated regret.

When going through the past literature, Moakhar et al. (2018b) found that post-purchase regret is directly affected by reversibility and the number of alternatives. But, as per Rajagopal et al. (2019), regret increases with the consideration of the product being purchased. Therefore, the regret with the alternative forgone increases. Ekici and Dogan (2013) also confirmed a positive relationship between the regret process of purchase and post-purchase levels. As per Ramprabha (2018), married women are more influenced by retail store factors than unmarried women. This statement was advanced by Deepak and Velaudham (2019), as unmarried consumers evaluate alternatives more than married consumers. Moakhar et al. (2018b) concluded that the number of alternatives forgone has a relationship with regret. According to Saleh (2012), post-purchase regret is more intensive among women in the Saudi region. A contraction was raised by Narahari and Kuvad (2017) concerning the Indian context, stating that there's no difference between men and women with shopping experiences and choices.

Women are proud to shop products for the best prices, and men purchase things instantly, except waiting for the best deals (Lakshmi, Niharika, \& Lahari, 2017). According to Srinivasan, Srivastava and Bhanot (2015), there is no relationship between marital status and the frequency of buying luxury products. Even though Moakhar et al. (2018b), and Botti and Iyengar (2004) have concluded the significant relationship between the number of alternatives forgone and post-purchase regret, no research was found with accessible resources about gender influence on the relationship mentioned above.

The main objective of this work is to investigate the moderating effect of the demographic factors with the relationship between postpurchase regret and alternatives forgone and return process experience. Identifying such relationships strengthens customer understanding, which is a crucial element in the marketing field of customer relationship management.

\section{Literature Review and Hypothesis Development}

Through literature, it has been concluded that there is a major effect from marital status to alternatives. The study of Armstrong, Abubakar, \& Sikayena (2017) reveals that the average level of post-purchase regret does not vary with the consumer's level of education and with gender. The current study was developed to address the moderating effect of this relationship. As per Ramprabha (2018), women of age 21 to 40 have more influence on merchandise, and women under the age of 21 prefer buying everything under one roof. Das (2017) stated that the number of alternatives at malls increases the excitement of shoppers. The current study extended to address the effect of moderation of income level for this relationship.

As per Armstrong, Abubakar, \& Sikayena (2017), the level of post-purchase regret does not differ with age. The study of Pei (2015) indicates that the consumer's age positively affects legitimate return behaviour. As a result, the following hypotheses were made to address the gaps found through literature and to clearly understand behavioural differences with respect to consumer demographics.

Hla: Age of the consumer does not moderate the relationship between the number of alternatives forgone and post-purchase regret at shopping malls in Sri Lanka

$H_{l b}$ : Gender of the consumer does not moderate the relationship between the number of alternatives forgone and post-purchase regret at shopping malls in Sri Lanka

$H_{1 c}$ : Marital status of the consumer does not moderate the relationship between the number of alternatives forgone and post-purchase regret at shopping malls in Sri Lanka

$H_{1 d}$ : Level of Education of the consumer does not moderate the relationship between the number of alternatives forgone and postpurchase regret at shopping malls in Sri Lanka

$H_{l e}$ : Career of the consumer does not moderate the relationship between the number of alternatives forgone and post-purchase regret at shopping malls in Sri Lanka

$H_{l f:}$ Income level of the consumer does not moderate the relationship between the number of alternatives forgone and post-purchase regret at shopping malls in Sri Lanka

According to Lakshmi, Niharika, \& Lahari (2017), there's a difference in purchasing behaviour concerning gender. For instance, in Sri Lanka, ladies are more forward to doing product returns. Though there are several findings related to the regret differences with respect to gender, moderating effect of gender on return procedure and post-purchase regret has not been investigated in the past. When considering the education levels of consumer, Pei (2015) have identified a positive effect of education on return behaviour. But contrastingly, Armstrong et al. (2017) findings did not reveal contrasting differences between customers' average level of postpurchase regret and their level of education. Due to these identified differences in the literature with respect to consumer demographics, the following hypotheses were developed for the Sri Lankan Context.

$H_{2 a}$ : Age of the consumer does not moderate the relationship between return procedure and post-purchase regret at shopping malls in Sri Lanka 
$H_{2 b}$ : Gender of the consumer does not moderate the relationship between return procedure and post-purchase regret at shopping malls in Sri Lanka

$H_{2 c}:$ Marital Status of the consumer does not moderate the relationship between return procedure and post-purchase regret at shopping malls in Sri Lanka

$H_{2 d}$ : Level of Education of the consumer does not moderate the relationship between return procedure and post-purchase regret at shopping malls in Sri Lanka

$H_{2 e}$ : Career of the consumer does not moderate the relationship between return procedure and post-purchase regret at shopping malls in Sri Lanka

$H_{2 f:}$ Income level of the consumer does not moderate the relationship between the number of alternatives forgone and post-purchase regret at shopping malls in Sri Lanka

The following figure shows the proposed study model for the above hypotheses.

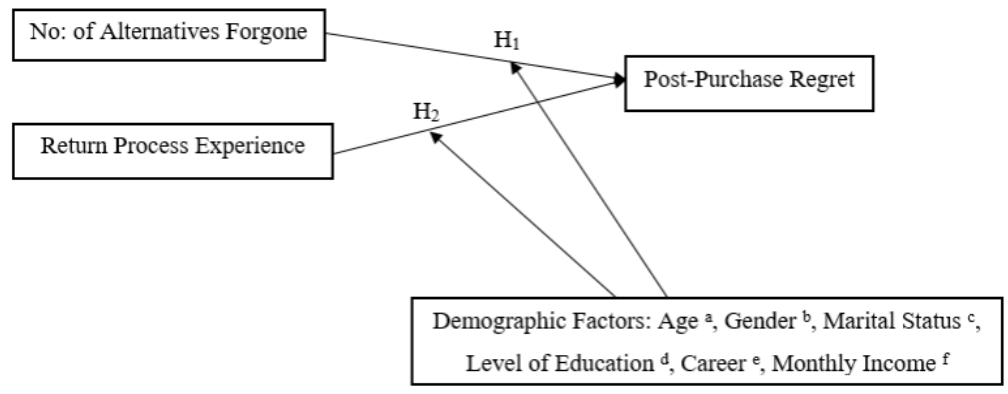

Figure 1: Study Model

\section{Research and Methodology}

\section{Variables and Measurement Scales}

The five-point Likert scale ranging from "strongly disagree" to "strongly agree" was used for each measuring item to gather information to address the situational regrets. The measurement scales for Number of Alternatives Forgone and Return Process Experience were adapted by referring to previously validated questionnaires. The designed questionnaire was translated to Sinhala (local language) and distributed to reach people incapable of understanding English. A pilot test was carried out to find the respondents' understandability, and further alterations were made.

The development of measurement constructs was done referring to fields of similar studies. For the variables "Post-purchase regret" and "Number of Alternatives Forgone", measurement constructs were derived from the study of Chen, Hui, \& Wang (2015). To construct measurements for "Return Process Experience", the study of Pei (2015) on consumers' product return behaviours was referred.

The analysis of the effect of demographic factors on self-esteem and risk-aversion relationship with post-purchase regret is discussed in this study. The study used the SPSS PROCESS Macro tool to identify moderating effect after fitting the regression model with self-esteem and risk-aversion. In multiple linear regression, the default model does not carry interaction effects. When interactions are ignored, the resulting model is incorrectly specified. Research is sound when including interaction effects.

\section{Data Collection}

As the initial step, the convenience sampling method was followed to gather primary data from the targeted sample, who have bought something from a shopping mall for the last two years. An online survey was conducted, and maximum reachable customers were chosen to minimize the error associated with the convenience sampling technique. Out of 475 collected responses, 383 were identified for this study after removing careless responses by calculating response biases.

Validity and reliability were checked using Statistical Package for the Social Sciences (SPSS) and the research hypotheses were tested by following structured equation modeling (SEM) techniques with the support of Analysis of Moment Structures (AMOS) statistical software.

\section{Analysis}

\section{Sample Profile}

The questionnaire contained some socio-demographic questions, and the final sample consisted of $43.6 \%$ male respondents and $56.4 \%$ female respondents. In terms of respondent age, $49.9 \%$ of people belonged to the age category of $21-30$. A minority (3.1\%) was aged below 20 years. The majority were single. It represented $43.6 \%$ of the sample, and $56.4 \%$ were married. The majority (54.6\%) of respondents have the bachelor's degree qualification as the highest educational qualification, while $23.8 \%$ of responses mentioned a post-graduate qualification. It was noted that the category of monthly income less than Rs. 20,000 or using parents' 
money was recorded as $36 \%$, while $13.6 \%$ had more than Rs 100,000 gain per month. The sample consisted of $31.3 \%$ of student respondents, and $22.7 \%$ were public sector employees.

\section{Reliability measurement}

As the initial step, exploratory factor analysis was undertaken to examine the internal consistency of the sample. The Maximum Likelihood Factoring Estimation with Promax Rotation was applied for the factor analysis. It was identified that three dimensions were in line with the design. The Kaiser-Meyer-Olkin (KMO) value was checked to verify sampling adequacy, and it resulted as 0.835 , which indicates high sampling adequacy. Further, the model explained $81.55 \%$ of the total variance. For each categorized factor, Cronbach's Alpha test resulted over 0.9 value (Post-purchase regret $=0.939$, Number of alternatives forgone $=0.973$, Return Process Experience $=0.915$ ), which implies the sample's reliability.

\section{Validating Measurement Model}

A Confirmatory factor analysis was carried out to check the validity of the constructs. The identified levels of construct fitness were Chi-square=189.645; Degrees of freedom $=33 ; \mathrm{P}=.000 ; \mathrm{CMIN} / \mathrm{DF}=5.747$ GFI $=.916 ; \mathrm{AGFI}=.861 ; \mathrm{NFI}=.971 ; \mathrm{CFI}=.933$; RMSEA $=.11$.

Using SEM, the following path diagram of the empirical casual model was developed. The factor loadings of statistically significant relationships are shown in the below figure.

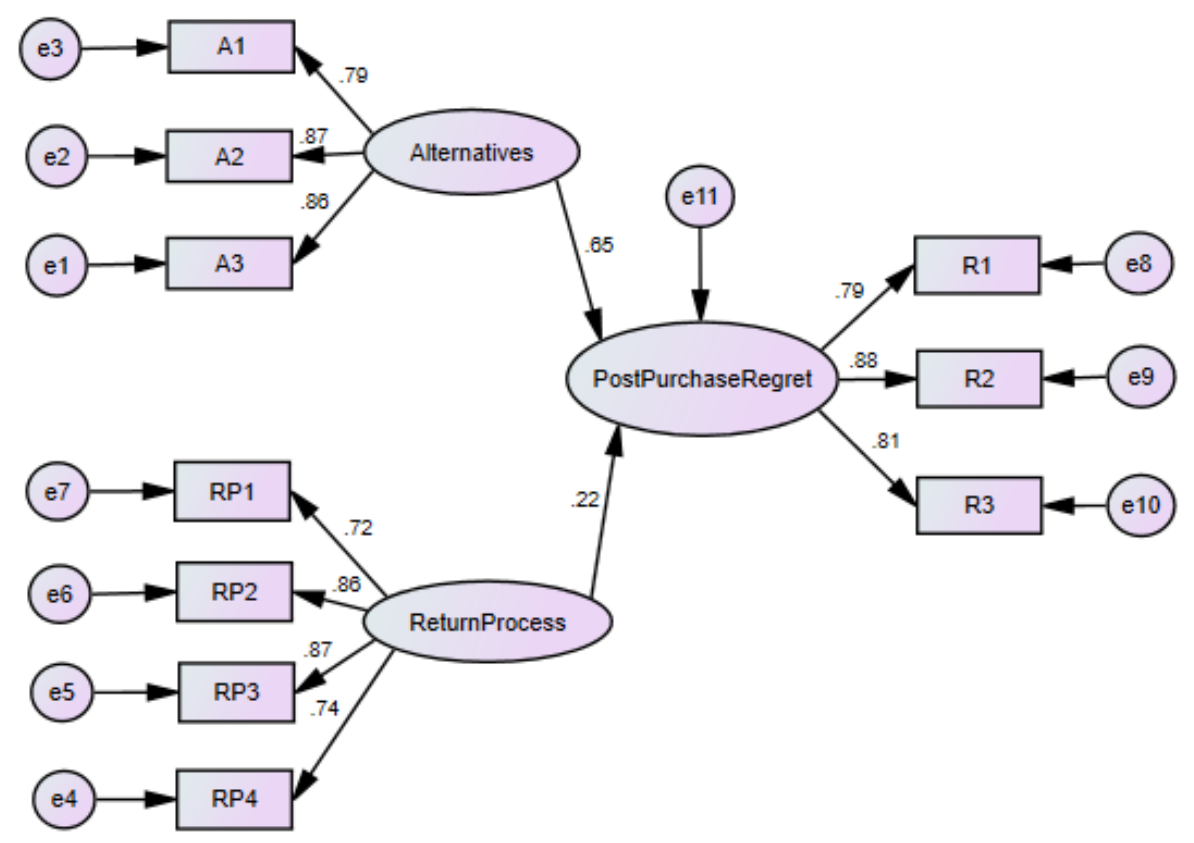

Figure 2: Empirical Casual Model (SEM) using AMOS

\section{Hypothesis Testing}

$H_{\text {la: }}$ Age of the consumer moderates the relationship between the number of alternatives forgone and post-purchase regret at shopping malls in Sri Lanka

The nested group path analysis was done to find the moderating effect of gender on the relationship between the number of alternatives forgone and post-purchase regret at shopping malls in Sri Lanka. According to the parameter estimates, the nested group examination indicated a non-significant difference among age categories $(\mathrm{P}=0.231)$ at a $5 \%$ significance level. Therefore it concludes that there's no enough evidence to reject the null hypothesis. Even though, when considering all four categories separately, all relationships were significant at 95\% confidence level, and the results are shown in Table 1.

Table 1: Relationship among, number of alternatives forgone and post-purchase regret concerning Age categories

\begin{tabular}{llcccc}
\hline Age & $<\mathbf{2 0}$ & $\mathbf{2 1 - 3 0}$ & $\mathbf{3 1 - 4 5}$ & $\mathbf{4 6 - 6 0}$ & $>\mathbf{6 1}$ \\
\hline Structural Estimate & 0.775 & 0.739 & 0.598 & 0.624 & 0.655 \\
\hline
\end{tabular}


It can be concluded that the highest significance showed by consumers aged below 20, with a standard regression weight of 0.775 while the lowest indicated as 0.598 standard regression weight. This implies a higher level of explanatory power with post-purchase regret and alternatives forgone with consumer's age below 20.

$H_{l b}$ : Gender of the consumer moderates the relationship between the number of alternatives forgone and post-purchase regret at shopping malls in Sri Lanka

The nested group examination for parameter estimates indicated a non-significant difference among males and females $(\mathrm{P}=0.239)$ at $5 \%$ level of significance. It concludes that there's no enough evidence to reject the null hypothesis. Although, study analysis was supported to identify significant relationships for both male and female groups at 95\% confidence level. Results are shown in Table 2.

Table 2: Relationship among, number of alternatives and post-purchase regret based on gender

\begin{tabular}{lll}
\hline Gender & Male & Female \\
\hline Structural Estimate & 0.599 & 0.698 \\
\hline
\end{tabular}

Test results imply that female consumers have a higher standard regression weight of 0.698 while male consumers indicated a 0.599 standard regression weight. This implies a higher level of explanatory power with post-purchase regret and alternatives forgone with females.

$H_{l c}:$ Marital status of the consumer moderates the relationship between the number of alternatives forgone and post-purchase regret at shopping malls in Sri Lanka

The nested group examination for parameter estimates indicated a non-significant difference among married and single $(\mathrm{P}=0.603)$ at a 5\% level of significance. It concludes that there's no enough evidence to reject the null hypothesis of moderating effect. When considering categories separately, both relationships were significant at a $95 \%$ level of confidence.

Table 3: Relationship among number of alternatives and post-purchase regret on marital status

\begin{tabular}{lcc}
\hline Marital status & Single & Married \\
\hline Structural Estimate & 0.703 & 0.576 \\
\hline
\end{tabular}

Considering two groups as two separate models, unmarried consumers have shown a significant standard regression weight of 0.703 while 0.576 for married consumers. A higher level of explanatory power with post-purchase regret and alternatives forgone with unmarried consumers were identified in this analysis.

$H_{1 d}$ : Level of Education of the consumer moderates the relationship between the number of alternatives forgone and post-purchase regret at shopping malls in Sri Lanka

The nested group examination for parameter estimates indicated a non-significant difference among married and single $(\mathrm{P}=0.238)$ at a 5\% level of significance. It concludes that there's no enough evidence to reject the null hypothesis Education level of the consumer moderates the relationship between the number of alternatives forgone and post-purchase regret. Regression weights are as follows in Table 4.

Table 4: Relationship among, number of alternatives forgone and post-purchase regret based on the education level

\begin{tabular}{lllll}
\hline Education level & High School & Diploma & Bachelor & Higher Education \\
\hline Structural Estimate & 0.524 & 0.529 & 0.735 & 0.598
\end{tabular}

Considering groups as separate models, high school consumers have shown insignificance while other categories indicate significance. It implies that educated customers have a higher level of explanatory power with post-purchase regret and alternatives forgone.

$H_{l e}$ : Career of the consumer moderates the relationship between number of alternatives forgone and post-purchase regret at shopping malls in Sri Lanka

The nested group examination for parameter estimates indicated a significant difference among different careers $(\mathrm{P}=0.03)$ at $5 \%$ level of significance. Thus, the null hypothesis can be rejected. It implies that the career of the consumer moderates the relationship between the number of alternatives forgone and post-purchase regret. Regression weights are as follows in Table 5. 
Table 5: Relationship among number of alternatives forgone and post-purchase regret concerning career of the customer

\begin{tabular}{llllll}
\hline \multicolumn{2}{l}{ Regression Weights } & & & Structural Weights \\
\hline Career (A) & Unconstrained & & & Estimate \\
\hline Student & Estimate & S.E. & C.R. & P & * \\
\hline Unemployed & 0.547 & 0.066 & 8.339 & $* *$ & 0.658 \\
\hline Self Employed & 0.428 & 0.255 & 1.287 & 0.1928 & 0.431 \\
\hline Private Sector Employee & 0.165 & 0.149 & 1.111 & 0.266 & 0.274 \\
\hline Public Sector Employee & 0.724 & 0.128 & 5.676 & $* * *$ & 0.646 \\
\hline Business Owner & 0.527 & 0.056 & 7.338 & $* * *$ & 0.538 \\
\hline Retired & 0.569 & 0.064 & 8.836 & $* * *$ & 0.638 \\
\hline
\end{tabular}

Considering groups as separate models, unemployed and self-employed consumers have shown insignificance while other categories indicate significance. Results imply that students and private sector employees give a higher level of explanatory power with postpurchase regret and alternatives forgone.

$H_{\text {If: }}$ Income level of the consumer moderates the relationship between the number of alternatives forgone and post-purchase regret at shopping malls in Sri Lanka

The nested group examination for parameter estimates indicated a non-significant difference among married and single $(\mathrm{P}=0.448)$ at a $5 \%$ level of significance. It concludes that there's no enough evidence to reject the null hypothesis income level of the consumer moderates the relationship between the number of alternatives forgone and post-purchase regret. Regression weights are shown in Table 6 .

Table 6: Relationship among number of alternatives forgone and post-purchase regret referred to income levels of customers

\begin{tabular}{lllll}
\hline Income (Rs.) & $<20000$ & $\mathbf{2 0 0 0 0 - 5 9 9 9 9}$ & $\mathbf{6 0 0 0 0 - 9 9 9 9 9}$ & $\mathbf{1 0 0 0 0 0 ~ o r ~ m o r e ~}$ \\
\hline Structural Estimate & 0.673 & 0.602 & 0.597 & 0.640 \\
\hline
\end{tabular}

As per the analysis, all paths were identified as significant. The greatest influence was noted from the income category of less than Rs.20,000.

$H_{2 a}$ : Age of the consumer moderates the relationship between the return Process experience and post-purchase regret at shopping malls in Sri Lanka

The nested group examination for parameter estimates indicated a non-significant difference in all age groups $(\mathrm{P}=0.685)$ at a $5 \%$ significance level. It concludes that there's no enough evidence to reject the null hypothesis age of the consumer moderates the relationship between the number of alternatives forgone and post-purchase regret. The below Table 7 shows the regression weights.

Table 7: Regression weights of the relationship among age, return process experience post-purchase regret at shopping malls in Sri Lanka

\begin{tabular}{llllll}
\hline Age & $<\mathbf{2 0}$ & $\mathbf{2 1 - 3 0}$ & $\mathbf{3 1 - 4 5}$ & $\mathbf{4 6 - 6 0}$ & $>\mathbf{6 1}$ \\
\hline Structural Estimate & 0.125 & 0.198 & 0.151 & 0.144 & 0.132 \\
\hline
\end{tabular}

According to the results, it is visible that only the consumers that belong to the age group of 21-30 has shown a significance while other categories indicated insignificance.

$H_{2 b}$ : Gender of the consumer moderates the relationship between the return Process experience and post-purchase regret at shopping malls in Sri Lanka

The nested group examination for parameter estimates indicated a non-significant difference between male and female consumers (P $=0.873$ ) at a $5 \%$ level of significance, concluding that there's not enough evidence to reject the null hypothesis on the gender-based moderation effect. Regression weights are shown in the table below.

Table 8: Regression weights of the relationship among gender, return process experience post-purchase regret at shopping malls in Sri Lanka

\begin{tabular}{lll}
\hline Gender & Male & Female \\
\hline Structural Estimate & 0.150 & 0.142 \\
\hline
\end{tabular}


$H_{2 c}$ : Marital Status of the consumer moderates the relationship between the return Process experience and post-purchase regret at shopping malls in Sri Lanka

The nested group examination for parameter estimates indicated a non-significant difference among married and single $(\mathrm{P}=0.873)$ at a 5\% level of significance, concluding that there's no enough evidence to reject the null hypothesis marital status of the consumer moderates the relationship between the number of alternatives forgone and post-purchase regret. Regression weights are shown in the table below.

Table 9: Regression weights of the relationship among marital status, return process experience post-purchase regret at shopping malls in Sri Lanka

\begin{tabular}{lcc}
\hline Marital status & Single & Married \\
\hline Structural Estimate & 0.147 & 0.102 \\
\hline
\end{tabular}

According to the results mentioned above, both single and married consumers showed insignificance.

$H_{2 d}$ : Level of Education of the consumer moderates the relationship between return procedure and post-purchase regret at shopping malls in Sri Lanka

The nested group examination for parameter estimates indicated a non-significant difference among all groups $(\mathrm{P}=0.10)$ at a $5 \%$ level of significance, concluding that there's no enough evidence to reject the null hypothesis education level of the consumer moderates the relationship between the number of alternatives forgone and post-purchase regret.

Table 10: Regression weights of the relationship among education level, return process experience post-purchase regret at shopping malls in Sri Lanka

\begin{tabular}{lllll}
\hline Education level & High School & Diploma & Bachelor & Higher Education \\
\hline Structural Estimate & 0.104 & 0.096 & 0.147 & 0.123 \\
\hline
\end{tabular}

According to the results, it is visible that only the high school consumers have shown significance while other categories indicated insignificance.

$H_{2 e}$ : Career of the consumer moderates the relationship between the return Process experience and post-purchase regret at shopping malls in Sri Lanka

The nested group examination for parameter estimates indicated a significant difference among all groups $(\mathrm{P}=0.01)$ at a $5 \%$ level of significance. Thus, the null hypothesis career of the consumer moderates the relationship between the number of alternatives forgone and post-purchase regret can be rejected.

Table 11: Regression weights of the relationship among career of the consumer, return process experience post-purchase regret at shopping malls in Sri Lanka

\begin{tabular}{llllll}
\hline \multicolumn{7}{l}{ Regression Weights } \\
Career (RP) & Unconstrained & & & Structural Weights \\
\hline Student & Estimate & S.E. & C.R. & P & Estimate \\
\hline Unemployed & 0.289 & 0.079 & 3.639 & $* * *$ & 0.303 \\
\hline Self Employed & 0.473 & 0.058 & 8.184 & $* * *$ & 0.189 \\
\hline Private Sector Employee & 0.328 & 0.233 & 1.405 & 0.160 & 0.112 \\
\hline Public Sector Employee & 0.010 & 0.187 & 0.054 & 0.957 & 0.259 \\
\hline Business Owner & 0.339 & 0.078 & 4.353 & $* * *$ & 0.287 \\
\hline Retired & 0.289 & 0.079 & 3.639 & $* * *$ & 0.292 \\
\hline & 0.473 & 0.058 & 8.184 & $* * *$ & 0.383 \\
\hline
\end{tabular}

The above results show that only the self-employed and Private sector employees have shown insignificance while other categories indicated a significance. The most significant influence was identified from retired consumers.

$H_{2 f:}$ Income level of the consumer moderates the relationship between the return Process experience and post-purchase regret at shopping malls in Sri Lanka 
The nested group examination for parameter estimates indicated a significant difference among all groups $(\mathrm{P}=0.155)$ at a $5 \%$ significance level. Thus, there's not enough evidence to reject the null hypothesis, the career of the consumer moderates the relationship between the number of alternatives forgone and post-purchase regret.

Table 12: Regression weights of the relationship among education level, return process experience post-purchase regret at shopping malls in Sri Lanka

\begin{tabular}{lllll}
\hline Income (Rs.) & $\mathbf{2 0 0 0 0}$ & $\mathbf{2 0 0 0 0 - 5 9 9 9 9}$ & $\mathbf{6 0 0 0 0 - 9 9 9 9 9}$ & $\mathbf{1 0 0 0 0 0 ~ o r ~ m o r e ~}$ \\
\hline Structural Estimate & 0.200 & 0.334 & 0.360 & 0.287 \\
\hline
\end{tabular}

Analysis indicates that consumers with an income level of Rs. 20,000- Rs. 59,999 and above Rs. 100,000 insignificance implication while other categories indicated a significant impact. Further results imply a higher level of explanatory power with post-purchase regret, and alternative forgone is given by income level category Rs. 60,000- Rs. 99,999.

\section{Findings}

\section{Moderating effect on the relationship between the number of alternatives forgone and post-purchase regret}

It was noted in previous studies that women tend to search more to have the best option, while men usually take a simple walk and decide an option to choose. It was further described that women are forward to shop with pride to select products for the best prices (Lakshmi, Niharika, \& Lahari, 2017). The current study supports the finding, gender of the consumer does not moderate the relationship between the number of alternatives forgone at the mall and post-purchase regret.

Concerning the gender of the customer, Ramprabha (2018) has stated that, married women are more influenced by retail store factors than unmarried women. As a further extension for this statement, Deepak and Velaudham (2019) found that unmarried consumers evaluate alternatives more than married consumers. Moakhar et al. (2018b), concluded that the number of alternatives forgone has a relationship with regret. From previous studies, it is visible that there is a major effect from marital status to choices within the shop. And the number of alternatives forgone directly affects post-purchase regret. To combine these statements, the current study searched for the influence of the consumer's marital status with the relationship between the number of alternatives forgone and post-purchase regret in shopping malls in Sri Lanka. Through the analysis, the nonexistence of interaction was recognized. It concludes that the consumer's marital status does not moderate the relationship between the number of alternatives forgone and post-purchase regret. Availability of alternatives necessarily drives the emotion of comparing over another with various specifications. At times like that, consumers choose a product considering price over its quality and durability. Therefore, it is better to investigate what type of products must be kept in showrooms of malls.

When going through the past studies, Armstrong, Abubakar, and Sikayena (2017) have stated that the average level of post-purchase regret does not vary with the consumer's level of education. Further, Ekanayake and Karunarathne (2021) noted that the alternatives forgone have positively affected the post-purchase regret at Sri Lankan Shopping Malls. In the current study, the relationship was modified with a moderating effect of the level of education of the consumer on the relationship between number of alternatives forgone and post-purchase regret. It was noted that consumers' level of education does not moderate the relationship. That defines educated people have not faced the same guilt over an unsatisfied product. They think of the alternatives they had, at least for once. The study has focused on shopping malls where most well-educated people tend to buy from. Therefore, Since there's no such difference in the education level of the respondents and since educated people in Sri Lanka mostly do mall shopping, the result is acceptable. And also, the Sri Lankan education system can be a great key to be the outcome.

Women of age 21 to 40 have more influence on promotion factors at the retail stores (Ramprabha, 2018). The regret could be appeared due to promotions with forgone alternatives if a person did not get a chance to consume the promotion. Even though Ramprabha (2018) has concluded on the intervention of age with alternatives forgone, the current study concludes a contradiction as the consumer's age does not moderate the relationship between the number of alternatives forgone and post-purchase regret. In fact, for the Sri Lankan context, it has resulted that all the age groups feel the same post-purchase regret in shopping malls with alternatives forgone. A feeling of guilt with a missing alternative could be the same with all the age gaps due to shopping as a family.

According to Das (2017) and Ekanayake and Karunarathne (2021), the number of alternatives at malls increases the excitement of shoppers, which leads to a positive impact on emotions. The current study focused on finding the moderating effect of income level on alternatives forgone and post-purchase regret relationship. It resulted in non-existence of moderating effect from income level for the relationship mentioned above. In Sri Lanka, malls have been built in highly populated areas and highly modernized areas. These malls attract people who have the affordability of high-end products. High quality, branded products and luxurious services are some reasons for the expensive rates in mall products. And also, there are several shops within the malls for each and every segment of products. For instance, if a person wants to buy a specific item, many outlets can be found in a shopping mall that sells the same item. According to the preference, they can buy it from any shop in the mall. The post-purchase regret appears after that. If a person had trouble choosing the best out of two products from two shops in the mall, it leads to regret alternative forgone, when the customer did not satisfy with the purchased product. Income level can be a reason to choose a product over another concerning price. But, in 
this study, the respondents had considerable income levels. And also, mall shopping is mainly done after considering the affordability. So the income level impact on alternatives forgone and post-purchase regret at Sri Lankan shopping malls is not considerable.

It resulted that as a career influences the relationship mentioned. Most of the time, a student can be identified as a dependent of a family. An alternative forgone by a student or an unemployed person can lead to a higher regret level than occupied consumers. It may have resulted from the source of funding. Though employed consumers spend their own earnings, students and unemployed consumers have to find a source for spending. It is a matter of how consumers accept regret with the amount of money spent. The current study represented a higher percentage of student respondents. So the outcome of career moderating the relationship between number of alternatives forgone and post-purchase regret is acceptable.

\section{Moderating effect on the relationship return procedure and post-purchase regret}

The level of post-purchase regret does not differ with age (Armstrong, Abubakar, \& Sikayena, 2017). Return procedure of the shop necessarily leads customers to revisit the shop (Pei, 2015). As per the current study, age does not moderate the relationship mentioned above. The reason might be, the survey responses mainly were completed by young people. And also, Sri Lankan shopping mall consumers are mostly young people. But, they shop with family. So the regret outcome, the loss is bared by the whole family. Concerning return procedure, it is a common procedure to everyone, and it is not concerned about the age of the consumer. So it can be argued that age does not take part as an intervention for the relationship between the return procedure of the mall shop and postpurchase behaviour.

The level of post-purchase regret does not differ with gender (Armstrong, Abubakar, \& Sikayena, 2017). A similar finding was identified in this study with gender interaction at shopping malls in Sri Lanka reference to the return procedure, post-purchase regret. Though Lakshmi, Niharika, and Lahari (2017) have found a difference in purchasing behaviour concerning gender, such differences in return procedure with gender were not identified in the Sri Lankan context. Concerning the Indian context also, Narahari and Kuvad (2017) argued that males and females have the same level of satisfaction at malls, A contradiction was raised with the study of Saleh (2012), rejecting the statement that post-purchase regret is more intensive among women.

Return procedures increase the number of sales and also the number of returns (Peterson \& Kumar, 2010). The study resulted that marital status does not moderate the relationship between return procedure and post-purchase regret at shopping malls in Sri Lanka. In fact, the mall itself has this return policy, and it does not depend on the consumer's marital status.

Education positively affects legitimate return behaviour (Pei, 2015). The statement further developed by Armstrong, Abubakar, and Sikayena (2017) as the average level of post-purchase regret does not vary with the consumer's level of education. Reversibility of the purchase decision is not a crucial factor to consider under post-purchase regret (Armstrong, Abubakar, \& Sikayena, 2017). Contrastingly for the Sri Lankan context, it was found that return process experience positively influences the post-purchase regret (Ekanayake \& Karunarathne, 2021). According to Narayan, Holly, \& Ryan (2016), a consumer can return a product with a policy given by the company with time duration (mostly 30-day product returns), as a refund, by showing the product price tag or receipt, or both. Although there are few concepts of return policies, none of them has affected with education level of the consumer when considering post-purchase regret.

Similarly, in the current study, it was found that the level of education of the consumer does not moderate the relationship between the return procedure of the mall shop and post-purchase regret. It is obvious that education does not affect it. These return policies are common for all the customers who shop at the mall. Hence, the regret that appears through the purchase cannot be explained by the level of education with the item return procedure of the mall.

It resulted that as a career influences the relationship mentioned. The reason behind this is, anyone can experience mall shopping. The occupation of the customer can be varied. The return process is a characteristic of the mall, and it only varies with the service behind it. It was found that the return process experience of the mall positively affects the post-purchase regret at the mall Ekanayake \& Karunarathne (2021). It is a matter of how consumers accept the return process and, how mall's shops deliver the return. Sometimes, people may fear returning a product because they believe it may negatively affect their profession. For example, a politician may feel guilty about exchanging a product than a civilian.

The consumer's income level positively influences legitimate and opportunistic return behaviors (Pei, 2015) and, consumers that have high-income tend to do returns more often legitimately and opportunistically. When returning a product, the return procedure is a major concern. The study resulted that income does not moderate the relationship between return procedure and post-purchase regret in Sri Lanka. This is because of the reason that mall shopping is usually done by middle-income people or high-income people in Sri Lanka. Because mall products are bit expensive than outside. So that, whenever a person wants to return a product, he/she is going through the same return process that others have gone through in the mall and he is able to do the return regardless of his income. Either a low-income person or a high-income person experiences the same regret or delightful experience with the return procedure of the mall shop. Accordingly, it leads to post-purchase regret level and behaviour. Therefore, the statement is acceptable. 


\section{Conclusions}

The findings of the moderation analysis conclude that the consumer's career is a critical factor towards the post-purchase regret at Sri Lankan shopping malls. However, the study was limited to independent variables of 'number of alternatives forgone' and 'return process experience'. These findings suggest that the number of available alternatives in the store must be arranged according to some marketing concepts. But the result can apply mostly to loyal customers. The staff in a shop must always try to memorize or get to know about the consumer's current occupation. This can be done through a friendly conversation with a staff member. So that, accordingly, the management must train salespersons about how it differs from the occupational factors. The salesperson is thereafter responsible for aiding the customer with alternatives evaluation by providing necessary information on durability, previous customer feedback, current demand for the alternative, etc. Then the post-purchase regret can be altered to a lower value.

Concerning the return process experience, the management can identify probable solutions to minimize the regret by providing a separate counter for exchange. The current study resulted as the career influences the return process experience and post-purchase regret relationship. Suppose a well-known or wealthy person wanted to exchange a product from that particular mall shop, the person might feel uncomfortable about the waiting in exchange counter with his/her status. In that scenario, it is better to handle an online exchange platform to feel at ease about returning a product. And also, the customer can replace a product to return a product by choosing a product from the store website after checking for any damage.

Unlike western countries, Asian countries tend to live with family and shop as a family. Thus, having a post-purchase regret due to a forgone alternative may not be severely affected than other regions. Since this finding is novel, further studies can be developed based on this statement. The result might be changed with geographical regions or in Western countries.

\section{References}

Armstrong, A., Abubakar, N. \& Sikayena, I. (2017). Investigating into factors accounting for cognitive dissonance (Post purchase regrets). International Journal of Multidisciplinary Research and Development, 4(3), 229-239.

Botti, S. \& Iyengar, S.S. (2004). The Psychological Pleasure and Pain of Choosing: When People Prefer Choosing at Cost of Subsequent Outcome Satisfaction. Journal of Personality and Social Psychology, 87(3), 312-326. https://doi.org/10.1037/0022-3514.87.3.312

Chen, J., Hui, E. \& Wang, Z. (2017). More promotion-focused, more happy? Regulatory focus, post-purchase evaluations and regret in the real estate market. Urban Studies, 54(1), 251-268. https://doi.org/10.1177/0042098015619320

Clarke, P.D. \& Mortimer, G. (2013). Self-gifting guilt: an examination of self-gifting motivations and post-purchase regret. Journal of Consumer Marketing, 30(6), 472-483. https://doi.org/10.1108/JCM-05-2013-0566

Das, G. \& Varshneya, G. (2017). Consumer Emotions: Determinants and Outcomes in a shopping mall. Journal of Retailing and Consumer Services, 38, 177-185. https://doi.org/10.1016/j.jretconser.2017.06.008

Deepak, K.R.A. \& Velaudham, C. (2019). Marital Differences Towards Customer Buying Behaviour. AJANTA International Multidisciplinary Quarterly Research Journal. 8(2), pp. 36-45.

Ekanayake, E.A.S.K. \& Karunarathne, E.A.C.P. (2021). Consumers' Post-Purchase Regret Determinants in Sri Lankan Shopping Malls. South Asian Journal of Social Studies and Economics, 11(4), 47-60. https://doi.org/10.9734/sajsse/2021/v11i430293

Ekici, N. \& Dogan, V. (2013). An Analysis of the Regret Concerning the Process of Purchasing and the Regret Concerning after the Purchasing in the Context of Characteristic Properties. International Journal of Marketing Studies, 5(6), 73-83. https://doi.org/10.5539/ijms.v5n6p73

Lakshmi, V.V., Niharika, D.A. \& Lahari, G. (2017). Impact of Gender on Consumer Purchasing Behaviour. IOSR Journal of Business and Management, 19(8), 33-36.

Moakhar, S.V., Shafigh, N., Kazemi, M., Zerafat, R., \& Kalantari, F. (2018a). Investigating post-purchase regret based on the situational factors of purchase in urban shopping centers. International Journal of Academic Research in Management, 7(1), 1-14.

Moakhar, S.V., Shafigh, N., Zerafat, R. \& Sohae, R. (2018b). The Effect of Regret Determinants on Consumers' Post-Purchase Behaviour in Urban Shopping Complex Building. Management Research and Practice, 10(2), 63-75.

Mollenkopf, D.A., Robinovich, E., Laseter, T.M. \& Boyer, K.K. (2007). Managing Internet Product Returns: A Focus on effective service operations. Decision Sciences, 38(2), 215-250. https://doi.org/10.1111/j.1540-5915.2007.00157.x

Myers, D. (2004). Construction Economics: A New Approach. New York: Taylor \& Francis.

Narahari, A.C. \& Kuvad, D. (2017) Customer Behaviour towards Shopping Malls- A Study in Bhavnagar (Gujarat State, India). International Journal of Advance Research and Innovative Ideas in Education, 3(2), 211-224.

Narayan, J., Holly, A. S. \& Ryan, F. (2016). The Effect of Return Policy Leniency on Consumer Purchase and Return Decisions: A Meta-Analytic Review. Journal of Retailing, 92(2), 226-235. https://doi.org/10.1016/j.jretai.2015.11.002Pei, Z. (2015). Internal and External Drivers of Consumer's Product Return Behaviours, North Texas: s.n.

Peterson, J.A., \& Kumar, V. (2010). Can Product Returns Make You Money?, MIT Sloan: Management Review, 51(3). Retrieved from https://sloanreview.mit.edu/article/can-product-returns-make-you-money/ 
Rai, J. \& Kimmel, J. (2015). Gender Difference in Risk Preferences: An Empirical Study Using Attitudinal and Behavioural Specifications of Risk Aversion. Research in Labor Economics, 42, 61-91. https://doi.org/10.1108/S0147912120150000042002

Rajagopal, K., Mahajan, V. Sharma, P. \& Udas, A. (2019). Effects on Consumer Behaviour due to post-purchase regret associated with Online Shopping. International Journal of Innovative Technology and Exploring Engineering, 8(11S), 548-555. https://doi.org/10.35940/ijitee.K1092.09811S19

Ramprabha, K. (2018). Assessing the influence of age and marital status of women consumers towards the retail dimensions of the supermarket. International Journal on Global Business Management and Research, 7(2), 39-43.

Saleh, M. (2012). An Investigation of the Relationship between Unplanned Buying and Post-purchase Regret. International Journal of Marketing Studies, 4(4), 106-120. https://doi.org/10.5539/ijms.v4n4p106

Srinivasan, R., Srivastava, R.K. \& Bhanot, S. (2015). Impact of Marital Status on Purchase Behaviour of Luxury Brands. IOSR Journal of Business and Management, 17(1), 82-93. https://doi.org/10.9790/487X-17718293

Tan, Y.C. \& Gan, C.C. (2014). The Role of Post-Purchase Emotional Dissonance on Product Return Intentions. Global Journal of Business and Social Science Review, 2(1), 89-98. https://doi.org/10.35609/gjbssr.2014.2.1(10)

Zou, T., Zhou, B. \& Jiang, B. (2020). Product-Line Design in the Presence of Consumer's Anticipated Regret. Management Science, 66(12), 5485-6064. https://doi.org/10.1287/mnsc.2019.3506

Publisher's Note: SSBFNET stays neutral with regard to jurisdictional claims in published maps and institutional affiliations.

\section{(a) (1)}

(C) 2021 by the authors. Licensee SSBFNET, Istanbul, Turkey. This article is an open access article distributed under the terms and conditions of the Creative Commons Attribution (CC BY) license (http://creativecommons.org/licenses/by/4.0/).

International Journal of Research in Business and Social Science (2147-4478) by SSBFNET is licensed under a Creative Commons Attribution 4.0 International License. 